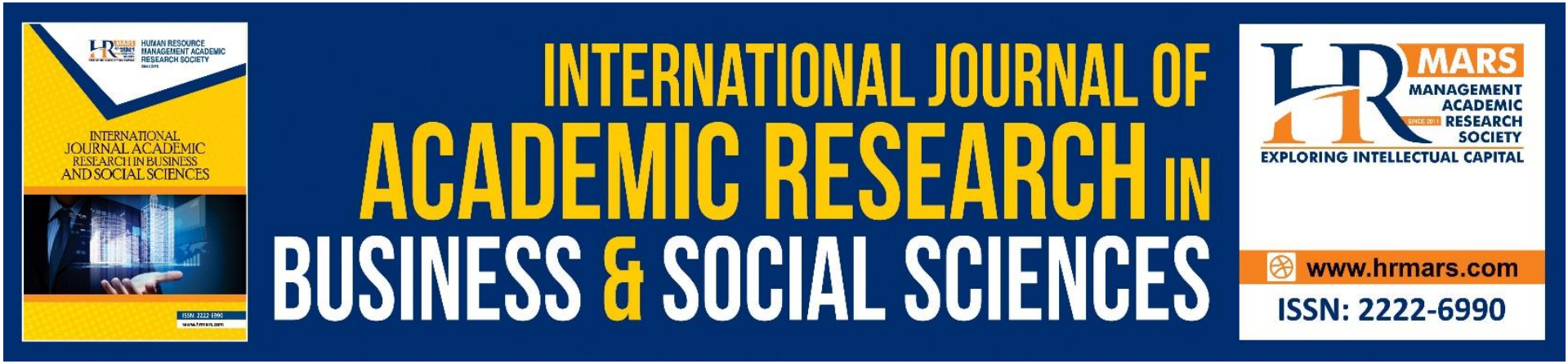

\title{
Level of Learning Style and Level of Students' Critical Thinking at Private Higher Learning Institutions
}

Baharuddin Puteh, Zurairah Jais, Muhammad Yasin Omar Mokhtar, Nor Ainee Idris, Wan Norhayati Wan Othman

To Link this Article: http://dx.doi.org/10.6007/IJARBSS/v11-i4/9770

DOI:10.6007/IJARBSS/v11-i4/9770

Received: 01 February 2021, Revised: 13 March 2021, Accepted: 15 March 2021

Published Online: 28 April 2021

In-Text Citation: (Puteh et al., 2021)

To Cite this Article: Puteh, B., Jais, Z., Mokhtar, M. Y. O., Idris, N. A., \& Othman, W. N. W. (2021). Level of Learning Style and Level of Students' Critical Thinking at Private Higher Learning Institutions. International Journal of Academic Research in Business and Social Sciences, 11(4), 1116-1126.

Copyright: @ 2021 The Author(s)

Published by Human Resource Management Academic Research Society (www.hrmars.com)

This article is published under the Creative Commons Attribution (CC BY 4.0) license. Anyone may reproduce, distribute, translate and create derivative works of this article (for both commercial and non-commercial purposes), subject to full attribution to the original publication and authors. The full terms of this license may be seen at: http://creativecommons.org/licences/by/4.0/legalcode

Vol. 11, No. 4, 2021, Pg. 1116 - 1126

Full Terms \& Conditions of access and use can be found at http://hrmars.com/index.php/pages/detail/publication-ethics 


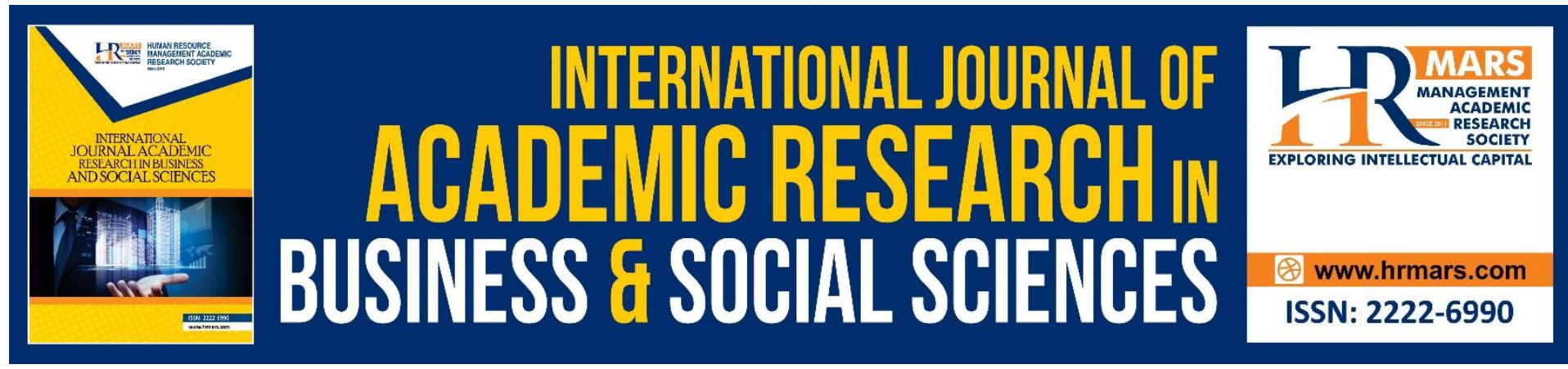

\title{
Level of Learning Style and Level of Students' Critical Thinking at Private Higher Learning Institutions
}

\author{
${ }^{1}$ Baharuddin Puteh, ${ }^{2}$ Zurairah Jais, ${ }^{3}$ Muhammad Yasin Omar \\ Mokhtar, ${ }^{4}$ Nor Ainee Idris, ${ }^{5}$ Wan Norhayati Wan Othman \\ ${ }^{1,4}$ Fakulti Bahasa \& Pendidikan, Kolej Universiti Islam Melaka, Malaysia, ${ }^{2}$ Fakulti Inovasi \\ Perniagaan \& Teknologi, Kolej Universiti Islam Melaka, Malaysia, ${ }^{3}$ Research Management \\ Centre, Kolej Universiti Islam Melaka, Malaysia, ${ }^{5}$ Faculty of Educational Studies \\ Universiti Putra Malaysia
}

\begin{abstract}
Students who study at a higher learning institutions have been independent in acquiring knowledge delivered by lecturers. This is closely related to the learning style of a student. Learning style plays an important role in determining the level of understanding of a student in a certain field in a certain university. This is due to the accurate learning style, it can identify the suitable method and strategy used in achieving a successful academic level. The objective of this research is to identify the learning style of students. Besides that, it is also to identify whether there is significant difference in the students' learning styles according to gender. Other than that, it is to identify the relationship of students' learning style towards students' critical thinking. The findings in this research showed positive signs in the effort in enhancing students' learning ability in innovation where it needs students to have creative and critical thinking. The comparison towards critical thinking based on students' gender showed that there is no significant difference of the level of critical thinking between male and female students. This means the critical thinking between male and female students are similar which is high.
\end{abstract}

Keywords: Learning Style, Critical Thinking

\section{Introduction}

Students who learn in a higher learning institution have independently gained knowledge delivered by lecturers. This is closely related to a student's learning style. The theory of learning style is how an individual acquires, processes and understands a new and difficult academic information (Yenise \& Aktamis, 2010; Abdullah et. Al 2010). This theory suggested the change in learning style in a more beneficial and systematic from a learning style that is more individualistic and traditional. Learning style consists of 6 main domains: a) free independent, managing learning on one's own and confidence with one's ability in learning. Next, b) avoid - giving excuses for not attending classes and learning the content of subjects, c) collaborative - comfortable when learning with others and through sharing of ideas, d) depending - students rely on teaching materials from lecturers after a frivolous learning, e) 
competitive - students learn competitively with other friends and have objectives in achieving recognition from lecturers and f) participate - students are diligent in attending classes and participate actively during learning session (Grasha \& Reichman, 2006; Ruslin, 2007; Siti Rahayah et. al 2006).

In a research by Abdullah et. Al (2017), they found that students who learn at a higher learning institution prefer collaborate learning, i.e learning together with others through idea sharing and also identified that higher learning institution students learn by avoidance in not attending classes.

Learning style plays an important role in determining the level of understanding of a student who studies at a higher learning institution. This is because through the accurate learning style, it can identify the suitable method and strategy to be used in achieving a proud academic level.

However, the ability to think critically is also seen to be able to contribute to the academic success to higher learning institution students. Critical thinking is the basic ability in life, work and it totally functions effectively in all aspects of life. The metaphor used by Edison in Sudarma (2013), life is like drumming. How many people can actually drum but not all can drum and play beautiful melody. People use their senses but not many who could use their senses in a healthy and critical way.

\section{Background}

Education system in Malaysia is said to be unsteady in terms of providing thinking skill to students (Nursafra et al., 2018). This is voiced out when the result of Programme for International Student Assessment (PISA) which indicated that Malaysia was ranked as the one third of the lowest in the international level (Wei, 2014; Ministry of Education Malaysia, 2012; Hashim et al., 2014) the transformation of - Order Thinking Skills (HOTS) was introduced through Malaysia Education Blueprint (2013-2025) is in line to remedy this situation.

This change is current in nature and the acceptance of Malaysians towards the terminology HOTS is so alien especially among educators. However, this terminology is so critical to be conceived and considered its practice particularly among students of higher learning institutions. This is supported by previous researches proving that within the process of teaching, thinking skills depicts confusion and understanding towards the concept of critical thinking, thus impacting to the less effective application in a system (Alazzi, 2005; Rosnanaini, 2003; Suhailah \&Edwar, 2012). The important elements consist in HOTS which is critical thinking has become the pushing factor towards the basic high thinking skills that emphasizes the aspect of logical and practical justification (Bailin et al., 1999; Mohd Zaidi, 2014, Mulnix, 2012).

The result from the research by Astika, et al. (2013), students who are passive in learning create silent class situation because the students are not active and quiet and only listen to what is being taught by their lecturer. This is an expository learning where learning is central around the lecturer. Astika, et al. (2013) also emphasized in his research findings, a lecturer is the source and the main information provider that the lecturer is very active in the learning process but the students are very passive, only receive and listen to every single explanation by their lecturer. This type of learning hinders the students from using their critical thinking skills like giving opinions, concluding a discussion, or arguing with classmates thus making their critical thinking less optimum. 


\section{Methodology}

The respondents of this study were the student of KUIM \& KUIS which were 861 in total. The study was conducted using the purposive sampling technique

\section{Research Objectives}

The objectives of this research are:

1. To identify students' learning style.

2. To identify whether there are differences in students' learning style based on gender.

3. To identify the relationship of students' learning style towards students' critical thinking.

\section{Research Hypotheses}

Ho1: there is no significant difference between male and female students' learning style. Ho2: There is no significant difference towards male and female students' critical thinking.

\section{Research Instruments}

\section{Critical Thinking}

The respondents of this study were the lecturers of KUIM and KUIS which were 861 in total. The study was conducted using the purposive sampling technique. The instrument used to measure is Critical Thinking and Learning Style

The measurement instrument of students' critical thinking is by using an instrument adapted from Malaysian Critical Thinking Instrument (MyCT). The original instrument has 62 items consists in 4 subconstructs: reasoning, analytical and logical, disposition and assumptions. However, in this research only subconstruct of disposition is being used in measuring students' critical thinking. There are 18 items being used to measure students' critical thinking disposition. 5- point Likert Scale is being used to measure students' responses about their critical thinking. The scale being used are: " 1 " as being "Strongly disagree"; " 2 " as "Dissagree"; "3" as "Less Agree"; " 4 " as "Agree", and " 5 " as "Strongly Agree".

\section{Learning Style}

The measurement instrument of students' learning style uses items by Reid (1984). This instrument consists of 30 items including six learning styles; visual, auditory, kinaesthetic, realistic, group and individual. The items in the instrument were translated and adapted accordingly for the use of higher learning institution students.

The construct of students' learning style are 6 subconstructs: visual, auditory, kinaesthetic, realistic, group and individual. 


\section{Research Findings}

Respondents' Profiles

Respondents are among 861 student teacher from two Islamic Private Higher Education Institutions. Respondents' compete profiles as in table 4

Table 4: Profiles of Research Respondents

\begin{tabular}{llcc}
\hline \multicolumn{1}{c}{ Background } & Respondents & Frequency & Percentage \\
\hline Gender & Male & 344 & 40.0 \\
& Female & 517 & 60.0 \\
\hline College & Kolej Universiti Islam Melaka & 416 & 48.3 \\
& Kolej Universiti Islam & 445 & 51.7 \\
& Antarabangsa Selangor & & \\
\hline Semester of Study & Five & 555 & 64.5 \\
& Six & 306 & 35.5 \\
\hline
\end{tabular}

A number of 344 (40.0\%) were male students and 517 (60.0\%) were female students. Majority of the respondents 555 (64.5\%) were semester five students and 306 (35.5\%) were semester six students. The respondents of this research were from two Islamic Higher Learning Institutions which 416 (48.3\%) were from Kolej Universiti Islam Melaka (KUIM) and 445 (51.7\% were from Universiti Islam Antarabangsa Selangor (KUIS).

\section{Level of Students' Learning Style}

Students' learning style has 30 items to measure six types of students' learning style such as visual, auditory, kinesthetic, realistic, group and individual. Table 5 shows mean score and standard deviation for every students' learning style.

Table 5 Mean Score and Standard Deviation of Every Subconstruct in Students' Learning Style

\begin{tabular}{lllll}
\hline & Sub-construct & Mean & SD & Interpretation \\
\hline 1 & Visual & 3.686 & 0.581 & High \\
2 & Auditory & 3.722 & 0.646 & High \\
3 & Kinesthetic & 3.738 & 0.671 & High \\
4 & Realistic & 3.777 & 0.644 & High \\
5 & Group & 3.692 & 0.679 & High \\
6 & Individual & 3.723 & 0.718 & High \\
\hline
\end{tabular}

Based on Table 5, is was found that the most dominant in students' learning style was the Realistic learning style (mean=3.777). this is followed by Linesthetic learning style (mean=3.738), Individual learning style (mean=3.723), Auditory learning style (mean=3.722), Group learning style (mean=3.692), and Visual learning style (mean=3.686). 


\section{Level of Students' Critical Thinking}

Level of students' critical thinking is measured by using 18 items. Table 6 showed mean score and standard deviation for every item in measuring students' critical thinking.

Table 6 Mean Score and Standard Deviation for Every Item for Students' Critical Thinking

\begin{tabular}{|c|c|c|c|c|c|}
\hline $\begin{array}{l}\text { Learning } \\
\text { Style }\end{array}$ & & Item & Mean & SD & $\begin{array}{l}\text { Interpreta } \\
\text { tion }\end{array}$ \\
\hline \multirow[t]{9}{*}{ Individual } & 1 & $\begin{array}{l}\text { I am able to evaluate } \\
\text { consistently when facing } \\
\text { problems related to learning. }\end{array}$ & 3.698 & 0.830 & High \\
\hline & 2 & $\begin{array}{l}\text { Every difficult learning } \\
\text { problem will be thought out } \\
\text { concretely. }\end{array}$ & 3.663 & 0.857 & Average \\
\hline & 3 & $\begin{array}{l}\text { In solving a problem, the main } \\
\text { thing to prioritize is to identify } \\
\text { the root cause of the problem. }\end{array}$ & 3.743 & 0.897 & High \\
\hline & 4 & $\begin{array}{l}\text { I will think and plan ahead of } \\
\text { what to do when I want to } \\
\text { solve a problem. }\end{array}$ & 3.824 & 0.858 & High \\
\hline & 5 & $\begin{array}{l}\text { Different opinions and } \\
\text { perspevtives are taken in } \\
\text { solving a problem. }\end{array}$ & 3.746 & 0.897 & High \\
\hline & 6 & $\begin{array}{l}\text { I am able to differentiate } \\
\text { logical or baseless reasoning } \\
\text { effectively. }\end{array}$ & 3.779 & 0.891 & Higg \\
\hline & 7 & $\begin{array}{l}\text { I am able to assess implied } \\
\text { meaning during a discussion. }\end{array}$ & 3.743 & 0.918 & High \\
\hline & 8 & $\begin{array}{l}\text { I am able to combine ideas } \\
\text { from various perspectives to } \\
\text { solve a problem. }\end{array}$ & 3.803 & 0.879 & High \\
\hline & 9 & $\begin{array}{l}\text { I use my own creativity in } \\
\text { trying to solve a problem. }\end{array}$ & 3.774 & 0.894 & High \\
\hline
\end{tabular}

continue

10 I consider many times before $3.800 \quad 0.879 \quad$ High deciding on a decision.

11 I reassess towards all solutions $3.731 \quad 0.923 \quad$ High being executed.

12 I think in detail towards all that $3.717 \quad 0.934 \quad$ High resulted from decisions I made.

13 Always keep trying to solve $\quad 3.773 \quad 0.926 \quad$ High any problems that occur. 
14 I will not stop trying as long as I do not find solutions to the problems that I have.

15 I am confident to be able to handle problem when I face new situation.

16 Surrounding factor will considered in solving a problem.

17 I am able to adapt in any situation.

18 I am comfortable to work with people from different culture.
3.7850 .911 High

3.7530 .882 High

$3.800 \quad 0.896 \quad$ High

$\begin{array}{lll}3.727 & 0.925 \quad \text { High }\end{array}$

$3.796 \quad 0.822 \quad$ High

$\begin{array}{llll}\text { Overall } & 3.759 & 0.519 & \text { High }\end{array}$

Overall, based on Table 6, it is found that students' critical thinking is at a high level (mean =3.759). Students are seen to have high ability to consistently assess when facing problems related to learning., in solving problem, the main thing that I will prioritize is to identify the cause of the problem, to think and to plan of what to do first in solving a problem taking into consideration various opinions and perspectives in solving a problem, able to differentiate logical and baseless reasoning effectively, able to assess implied meaning during discussion, always combine ideas from different perspectives in solving a problem, using own creativitiy in solving the problem faced, assessing a decision many times before making a decision, reassess towards all solutions being executed, to think in detail towards all that resulted from decisions made, always keep trying to solve any problems that occur, will not stop trying as long as no solutions found to the problems that I have, confident to be able to handle problem when facing new situation, surrounding factor is put into consideration in solving a problem, easily adapt to any situation and comfortable to work with people from different culture. However, on the average, students only think concretely to every difficult learning problem. 


\section{Comparison of Students' Learning Style Based on Gender}

$\mathrm{Ho}_{1}$ : There are no significant difference between male and female students.

The result from $\mathrm{t}$-Test analysis in assessing $\mathrm{Ho}_{1}$ is as in Table 7.

Table 7 : t-Test Comparison of Students' Learning Style Based on Gender

\begin{tabular}{llrrrrc}
\hline $\begin{array}{c}\text { Learning } \\
\text { Style }\end{array}$ & Gender & Number (n) & Mean & s,d & Value-t & $\begin{array}{c}\text { Sig } \\
\text { Level, }\end{array}$ \\
\hline VISUAL & Male & 344 & 3.656 & 0.603 & -1.220 & 0.223 \\
& Female & 517 & 3.706 & 0.566 & & \\
\hline AUDITORY & Male & 344 & 3.656 & 0.686 & -2.459 & $\mathbf{0 . 0 1 4 ^ { * }}$ \\
& Female & 517 & 3.766 & 0.615 & & \\
\hline KINESTHETIC & Male & 344 & 3.701 & 0.731 & -1.345 & 0.179 \\
& Female & 517 & 3.764 & 0.628 & & \\
\hline REALISTIC & Male & 344 & 3.707 & 0.707 & -2.167 & $\mathbf{0 . 0 0 1 ^ { * }}$ \\
& Female & 517 & 3.824 & 0.595 & & \\
\hline GROUP & Male & 344 & 3.648 & 0.728 & -1.542 & 0.123 \\
& Female & 517 & 3.721 & 0.643 & & \\
\hline INDIVIDUAL & Male & 344 & 3.650 & 0.770 & -2.424 & $\mathbf{0 . 0 1 6 *}$ \\
& Female & 517 & 3.771 & 0.677 & & \\
\hline
\end{tabular}

*Sig at level $p<0.05$

Based on Table 6 it is found that there is no significant difference at the visual learning style $(t=-1.220 ; p=0.223)$, kinesthetic $(t=-1.345 ; p=0.179)$ and group $(t=-1.542 ; p=0.123)$ between male and female students. This means the visual, kinesthetic and group learning style between male and female students is at the same level.

However, there is significant difference at the auditory learning style $(t=-2.459$; $\mathrm{p}=0.014)$, realistic $(\mathrm{t}=-2.167 ; \mathrm{p}=0.001)$ and individual $(\mathrm{t}=-2.424 ; \mathrm{p}=0.016)$ between male and female students. Auditory learning style $(\min =3.766)$, realistic $(\min =3.824)$ and individual ( $\min =3.771$ ) female students are higher in comparison to the auditory ( $\min =3.656$ ), realistic ( $\min =3.707)$ and individual ( $\min =3.650)$ male students.

\section{Comparison of Critical Thinking based on Gender}

$\mathrm{Ho}_{2}$ : There is no significant difference of critical thinking level between male and female students.

Result from $\mathrm{t}$ - Test analysis in assessing $\mathrm{Ho}_{3}$ is as in Table 4.17.

Table 8: t-test Comparison of Critical Thinking based on Gender

\begin{tabular}{lrrlcc}
\hline \multicolumn{1}{c}{ Gender } & Number $(n)$ & Mean & s,d & Value-t & Sig Level, \\
\hline Male & 344 & 3.766 & 0.527 & 0.297 & 0.767 \\
Female & 517 & 3.755 & 0.513 & & \\
\hline
\end{tabular}

Based on Table 8 it is found that $\mathrm{t}$-value for the comparison of students' critical thinking is at $t=0.297$ and the significant level is at 0.767 . this level of significant is bigger than 0.05 $(p>0.05)$. therefore, null hypothesis $\left(\mathrm{Ho}_{3}\right)$ failed to be rejected or accepted. Therefore, there is no significant difference of the critical thinking level between male and female students. This means male students' critical thinking (mean=3.766) and female students (mean=3.755) is at the same level which is high. 


\section{Discussion}

Besides lecturers' instructional leadership, students' learning style is also an important aspect in determining students' excellence. Learning style is an important construct resulted from the factors of cognitive, affective and psychology and it can affect a student's responses towards information that he or she received (Kolb, 1984)

Students' learning style in this research context involves 6 students' learning style namely auditory, kinaesthetic, realistic, group and individual. This research found that students' most dominant learning style is the Realistic learning style. This is followed by Kinesthetic learning style, Individual learning style, Auditory learning style, Group learning style and Visual learning style. Learning style is the preferred and opted style by students in processing information that they received (Schunk 1991). The determination of learning style is important so that lecturers can sync the suitable teaching method and technic to students' learning style in ensuring the effectiveness of the teaching.

Dunn and Dunn (1978) emphasized that students not only can identify their favourite learning style but also they can score higher in their test, having a better attitude and more effective if they are taught with the method that they easily relate to. Therefore, it is an advantage for teachers to teach and test their students in their favourite learning style. Although learning styles among students are different, Dunn and Dunn (1978) said that a teacher should try to make changes in their class that can benefit to every learning style.

The comparison of students' learning style based on gender shows that there is no significant difference in visual, kinesthetic and group learning style between male and female students. This means learning style of visual, kinesthetic and group between male and female students is at the same level. However, there is significant difference in the learning style auditory, realistic and individual between male and female students. The learning style of auditory, realistic and individual of female students is higher in comparison to the learning style of auditory, realistic and individual of male students.

This research found that the overall students' critical thinking is at a high level. Students are seen to have high competency in consistently able to assess when facing problems related to learning, solving problems, the main thing I will prioritize is to identify the cause of the problem, to think and plan first of what to do when solving a problem, considering various opinions and perspectives in solving a problem, able to differentiate rightful and logical reasoning effectively and vice versa, able to assess implied meaning during discussion, always combine ideas from different perspectives to solve a problem, using own creativity in solving a problem, considering many times before making a decision, reassess towards all problem solving methods executed, to think in detail towards the implications resulted from decisions made, always keep trying to solve any problem, will not stop trying as long as no solutions found to the problems that I have, confident to be able to handle problem when facing new situation, surrounding factor is put into consideration in solving a problem, easily adapt to any situation and comfortable to work with people from different culture. However, on the average, students only think concretely to every difficult learning problem. 
The finding from this research shows a positive sign in the effort to increase students' ability in innovation where it needs students to ne creative and critical. This critical skill is one of the soft skills that needs to be nurtured when students are at a

higher learning institution. Thus, lecturers' main role is not only to deliver knowledge in enhancing students' academic excellence but also to develop students' holistically and balanced physically, emotionally, spiritually and intellectually as recorded in the National Education Philosophy.The comparison of students' critical thinking level based on gender shows that there is no significant difference between the criticak thinking level between male and female students. This means that male and female students' critical thinking is at the same level which is high.

\section{Conclusion}

A better knowledge and understanding about students' learning style is important due to the increment of class/lecture size as well as the advancement of technology continue to shape the type of students who enter higher education. Although the research about students' learning style will continue to flourish, lecturers particularly in the Islamic higher learning institutions need to focus their effort to teach in various styles, where they can reach a higher level that students are able to give in class and to challenge all students to succeed. This is vital in understanding and exploring every student's learning style. Lecturers can combine learning styles in their lectures by identifying every student's style, matching the style of teaching with the style of learning in any difficult task, enforcing the weak learning style through a simpler task and drilling, and teaching students of the strategy of choosing the style of learning. This is important for students who have access towards multiple learning styles and lecturers need to obtain the comparability between the strategy of teaching and students' learning style. In adjusting the teaching with learning style can enhance the students' learning outcome holistically, as found in this research that learning style does affect students' academic achievement, enhancing motivation, efficiency and having a positive attitude towards the subjects learnt. The purpose in using learning style is to find the best way for students to learn effectively, whereas teachers can teach more productively and effectively.

\section{Acknowledgement}

This research received no specific grant from any funding agency in the public, commercial or not-for-profit sectors.

\section{Corresponding Author}

Zurairah binti Jaiz

Fakulti Inovasi Perniagaan \& Teknologi Kolej Universiti Islam Melaka

Email: zurairah@kuim.edu.my

\section{References}

Dunn, R., \& Dunn, K. (1978). Teaching students through their individual learning styles. Reston, VA: Reston.

Grasha, A. F. (1996). Teaching with style: A practical guide to enhancing learning by understanding teaching and learning styles. San Bernardino, CA: Alliance Publishers.

Grasha, A. F., \& Riechmann, R (2006). Teaching Style Survey. Retrieved on 2006 from web address: http://longleaf.net/teachingstyle.html 
Kolb, D. A. (1984). Experiential learning: Experience as the source of learning and development (Vol. 1). Englewood Cliffs, NJ: Prentice-Hall

Nursafra, M. Z., Wan, A. A. W. A., Mohd, I. H., K. A. R., Maimun, A. L. (2018). Strategi Penyoalan Guru Pendidikan Islam dalam Pengajaran Berfikir Kritis. ASEAN Comparative Education research Hournal n Islam and Civilization (ACER-J). Vol 2(1), 72-87, elSSN:2600-769X

Rosnani, H., Suhailah, H., Adesile, M. I. (2014). Hikmah (wisdom) pedagogy and students' thinking and reasoning abilities Intellectual DIscourse, 22:2 (2014) 119-138

Amir, R. (2007). Stail Berfikir, Stai Pengajaran dan Stail Pembelajaran Pensyarah dan Pelajar UKM. Tesis Dr.Fal. Universiti Kebangsaan Malaysia.

Amir, R. (2007). Stail Berfikir, Stail Pengajaran dan Stail Pembelajaran Pensyarah dan Pelajar UKM. ljazah Kedoktoran Fakulti Pendidikan: UKM Bangi.

Schunk, D. H., \& Swartz, C. W. (1991). Goals and progress feedback: Effects on self-efficacy and writing achievement. Unpublished manuscript, University of North Carolina, Chapel Hill.

Siti, R. A., Noriah, M. I., \& Saemah, R. (2006). Melbourne, Australia. Profiling of Multiple Intelligences Test among youth in Malaysia. Proceeding for Teaching and Learning Conference.

Siti, R. A., Noriah, M. I., Abdul, G. A., Roslin, A., \& Mohd, K. M. J. (2008). Manual penggunaan Electronic System of Multiple Intelligences and Learning Styles (e-MILes).

Sudarma. (2013). Profesi Guru Dipuji, Dikritis,Dan Dicaci, Jakarta: PT Rajagrafindo Persada

Suhailah H., \& Lisa E. (2012). Creating dialogues in the Islamic studies classrooms: a comparative study of traditional pedagogy vs. critical pedagogy. In 8th World Conference on Muslim Education 2012, Shah Alam, Selangor, 12-13th Nov.

Sulaiman, R. (2003) Pelaksanaan Pendekatan Pengajaran Kemahiran Berfikir Dalam Mata Pelajaran Sejarah: Satu Kajian Kes. Ph.D. Thesis, Universiti Kebangsaan Malaysia. Bangi.

Yenice, N., \& Aktamis, H. (2010). Determination of multiple intelligence domains and learning styles of the teacher candidates. Procedia Social and Behavioral Sciences, 2, 32743281. http://dx.doi.org/10.1016/j.sbspro.2010.03.501

Yenise, N., \& Aktamis, H. (2010). Determination of Multiple Intelligence Domains and Learning Style of the Teacher Candidates. Procedia Social and Behavioral Sciences 2, 32743281. 